\title{
A SHORT STORY READING SECTION AS AN ALTERNATIVE WAY TO IMPROVE STUDENT'S LITERACY IN SD N 6 PANJER KEBUMEN
}

\section{Dwi Novitasari, Eka Fajriatul Janah, Muhamad Chamdani}

Universitas Sebelas Maret novitasaridwi222@gmail.com

\section{Article History}

accepted 30/09/2018

approved12/10/2018

published 30/10/2018

\section{Keywords}

reading short stories, literacy

\begin{abstract}
The goverment made changes to the Indonesian education curriculum of the education unit level curriculum into the curriculum of 2013. Changes in the curriculum in 2013 lies in the preparation of the RPP (Lesson Plan) and the ability of literacy. The emphasis on the preparation of the RPP has been resolved with the holding of training, but to literacy still unwell. One way to improve the literacy skills is through the reading of short stories. The reading of the short story aims to help improve reading skills and knowledge of sentence patterns, so it can be an idea to create an article. The focus on this study include: (1) The concept of reading a short story; (2) The impact of short story readings. These studies include: (1) The reading of short stories is an activity habituation to read a fictional narrative prose text .; (2) The impact resulting from the reading of short stories such as enhancing the knowledge, encourage the growth likes to read, and to foster the ability to write.
\end{abstract}

Social, Humanities, and Education Studies (SHEs): Conference Series https://jurnal.uns.ac.id/shes
p-ISSN 2620-9284 e-ISSN 2620-9292 


\section{PENDAHULUAN}

Literasi merupakan salah satu kemampuan yang penting sebagai upaya "pengkayaan" pengetahuan. Dengan kata lain, literasi sama halnya dengan jendela dunia. Melalui literasi seseorang dapat mengetahui informasi, pengetahuan, dan keterampilan, karena literasi meliputi kegiatan membaca dan menulis. Melalui kegiatan membaca dapat meningkatkan pengetahuan tentang berbagai informasi sekaligus pengetahuan tentang bagaimana cara merangkai kata, pola kalimat, berbagai ketentuan menulis, ditambah dengan wawasan pengetahuan. Melalui kegiatan membaca, dapat berimplikasi pada kemampuan menulis seseorang baik itu menumbuhkan atau meningkatkan keterampilan menulisnya.

Menteri Koordinator Bidang Pembangunan Manusia dan Kebudayaan (PMK) Puan Maharani di gedung Perpustakaan Nasional Jakarta pada senin 26 Maret 2018 dikutip dari kompas.com menyatakan bahwa berdasarkan hasil penelitian perpustakaan nasional tahun 2017, rata-rata orang Indonesia hanya membaca buku 34 kali per minggu, dengan durasi waktu membaca per hari rata-rata 30-59 menit. Sedangkan jumlah buku yang ditamatkan per tahun rata-rata hanya 5-9 buku. Menurut data statistik UNESCO tahun 2017 (cnnindonesia.com) dinyatakan bahwa dari 61 negara, Indonesia berada pada peringkat ke 60 dengan literasi rendah. Terdapat beberapa faktor yang menyebabkan rendahnya minat baca masyarakat Indonesia diantaranya yaitu karena kebiasaan membaca yang belum ditanamkan sejak dini, fasilitas dan kualitas sarana pendidikan yang kurang merata, dan masih kurangnya produksi buku berkualitas di Indonesia. Masalah kualitas sarana pendidikan dan kurangnya produksi buku berkualitas di Indonesia bukanlah faktor utama penyebab rendahnya literasi di Indonesia, karena meskipun sarana dan buku berkualitas tersedia apabila tidak terdapat keinginan dari diri sendiri untuk memanfaatkan sarana dan buku yang tersedia. Dari sinilah, perlu disadari pentingnya menanamkan kebiasaan membaca kepada seseorang.

Pembudayaan literasi dapat dinilai sangat baik untuk diterapkan sejak dini, karena pada usia dini seseorang lebih mudah menyerap pengetahuan, pengalaman, dan membentuk kebiasaan. Pembudayaan literasi dimulai dari lingkungan sekolah dengan dukungan keluarga. Kegiatan pembudayaan literasi dapat dimulai dari pembacaan teks yang dapat diterapkan di kelas rendah yaitu kelas satu, dua, dan tiga sekolah dasar sehingga selain dapat melatih anak untuk berliterasi dan menambah pengetahuan, juga dapat bermanfaat untuk melatih kemampuan membaca siswa kelas rendah.Kegiatan pembudayaan literasi ini menjadi salah satu wujud upaya pemenuhan tugas seorang guru terhadap tuntutan yang berlaku saat ini dimana literasi menjadi salah satu kemampuan yang ditekankan seiring dengan berlakunya kurikulum 2013. Meskipun sudah berlaku selama hampir 6 tahun, namun kemampuan literasi siswa masih rendah. Hal ini ditandai dengan literasi Indonesia yang berada pada peringkat dua terendah. Peringkat yang sangat memprihatinkan terlebih dengan status negara dengan penduduk keempat terbesar di dunia.

Berdasarkan pemaparan yang telah dikemukakan di atas, pada kesempatan ini penulis ingin mengkaji sebuah gagasan pembacaan cerita pendek sebagai alternatif untuk meningkatkan kemampuan literasi siswa SD Negeri 6 Panjer, sehingga dapat dirumuskan beberapa hal mengenai konsep pembacaan cerita pendeksebagai alternatif untuk meningkatkan kemampuan literasi siswa SD Negeri 6 Panjer, konsep literasi baca tulis, dan manfaat pembacaan cerita pendek terhadap kemampuan literasi siswa SD Negeri 6 Panjer. Tujuan dari kajian ini adalah untuk menambah pengetahuan mengenai konsep pembacaan cerita pendeksebagai alternatif untuk meningkatkan 
kemampuan literasi siswa SD Negeri 6 Panjer, mengetahui konsep literasi baca tulis, dan manfaat pembacaan cerita pendek terhadap kemampuan literasi siswa SD Negeri 6 Panjer.

\section{METODE}

Metode yang digunakan dalam kajian ini adalah studi kepustakaan. Nazir (2003) mengemukakan bahwa "Studi kepustakaan adalah teknik pengumpulan data dengan mengadakan studi penelaahan terhadap buku-buku, literature-literatur, catatancatatan, dan laporan-laporan yang ada hubungannya dengan masalah yang dipecahkan". Peneliti melakukan kajian teori dengan mengumpulkan informasi dari kepusakaan yang sesuai dengan tema literasi.

\section{PEMBAHASAN}

\section{A. Konsep Pembacaan Cerita Pendek}

Rahim (2009: 2) mengartikan membaca sebagai sesuatu yang rumit yang melibatkan aktivitas melafalkan tulisan, aktivits visual, berpikir, psikolinguistik, dan metakognitif. Haryadi (2012: 4) mengartikan membaca sebagai salah satu keterampilan berbahasa yang termasuk di dalam retorika seperti keterampilan berbahasa lainnya (berbicara dan menulis).

Syafi'ie (Rahim, 2009: 2) memaparkan bahwa terdapat tiga istilah untuk memberikan komponen dasar membaca, yaitu recording, decoding, dan meaning. Recording merujuk pada kata dan kalimat yang diasosiasikan dengan bunyi-bunyian sesuai dengan sistem tulisan yang digunakan. Decoding yaitu proses penerjemahan rangkaian grafis ke dalam kata-kata. Kedua proses ini terjadi pada SD kelas rendah. Sedangkan meaning yang merupakan proses memahami makna terjadi pada SD kelas tinggi.

Philips (Ghazali, 2013: 186-187) mengemukakan suatu model membaca yang mengintegrasikan keterampilan menyimak dengan keterampilan kognitif yang melibatkan bidang-bidang lain seperti berbicara dan menulis yang dirinci dalam beberapa tahap berikut: 1) Tahap persiapan atau pra-pengajaran, dimana siswa mendengarkan sebuah pengantar singkat tentang teks yang akan didengarkan, seperti judul, kalimat pertama, atau beberapa kutipan frase dari teks. 2) Tahap menyimak secara sekilas, dimana siswa mendengarkan teks dengan tujuan untuk menangkap garis besar dari teks itu tanpa perlu menangkap semua rinciannya. 3) Tahap pemahaman, dimana siswa menerima masukan yang diberikan dengan cara memeriksa pemahaman siswa terhadap keseluruhan teks. 4) Tahap transfer/integrasi keterampilan, dimana siswa menjabarkan teks yang didengarkan ke dalam bahasa lisan atau tulis.

Dunkel (Ghazali, 2013: 187) berpendapat bahwa guru perlu memberikan kegaiatan mendengar dalam jumlah besar dengan berbagai jenis wacana lisan yang otentik dengan menggunakan sarana audio dan video.

Ghazali (2013: 205) menyatakan bahwa membaca bisa dipandang sebagai sebuah sumber dari input bahasa yang memengaruhi perkembangan kemampuan menulis, kerna membaca dan menulis bersifat timbal balik dan dipengaruhi oleh faktorfaktor seperti level profisiensi, karakteristik pembelajar dan pendekatan pengajaran yang digunakan.

Membaca dalam bahasa kedua bisa diambil dari genre sastra seperti naskah drama, cerita pendek, esai, puisi dan novel Ghazali (2013: 205). 
Berdasarkan pemaparan di atas, jenis bacaan yang dinilai sesuai untuk siswa SD terutama untuk kelas rendah adalah cerita pendek yang merupakan salah satu prosa fiktif naratif/narasi fiksi sehingga dengan mudah dapat dengan mudah disesuaikan dengan karakteristik anak.

Nurgiyantoro (dalam Kurniawan, 2009: 30) mengemukakan bahwa "fiksi menampilkan cerita khayal yang tidak menunjuk pada kebenaran factual atau sejarah". Dari pendapatnya ini, fiksi dinilai ringan dan sesuai untuk diberikan kepada siswa SD.

Lebih lanjut, Kurniawan (2009: 30-31) mengemukakan bahwa fiksi diungkapkan dalam bentuk narasi atau cerita yang membahas tentang pengalaman kehidupan dalam bentuk naratif. Fiksi anak terdiri dari dua subgenre, yaitu fiksi tradisional seperti dongeng dan cerita rakyat, dan fiksi modern seperti cerpen dan novel.

\section{B. Literasi Baca Tulis}

Saryono, dkk (2017:5) mengartikan literasi baca-tulis sebagai pengetahuan bacatulis, kemampuan memahami baca-tulis, dan kemampuan menggunakan bahasa tulis. Senada dengan itu, dalam Peta Jalan GLN (Saryono, dkk, 2017: 5) literasi baca-tulis dapat diartikan sebagai pengetahuan dan kemampuan membaca dan menulis, mengolah dan memahami informasi saat melakukan proses membaca dan menulis, serta kemampuan menganalisis, menanggapi, dan menggunakan bahasa.

Dari beberapa pendapat di atas dapat disimpulkan bahwa literasi baca-tulis merupakan sebuah pengetahuan dan kecakapan untuk membaca, menulis, mencari, menelusuri, mengolah dan memahami informasi untuk menganalisis, menanggapi, dan menggunakan teks tertulis untuk mencapai tujuan, mengembangkan pemahaman dan potensi, serta untuk berpartisipasi di lingkungan sosial.

Menurut Saryono, dkk (2017: 6) literasi baca-tulis dikembangkan dan diimplementasikan berlandaskan pada lima prinsip dasar, yaitu: a) Holistik, artinya literasi baca-tulis dikembangkan dan diimplementasikan secara utuh-menyeluruh (holistik), tidak terpisah dari aspek terkait yang lain dan menjadi bagian elemen yang terkait dengan yang lain, baik internal maupun eksternal. Pengembangan dan implementasi literasi baca-tulis di ranah sekolah, keluarga, dan masyarakat juga merupakan satu kesatuan dan keutuhan, harus saling mendukung dan memperkuat, tidak merintangi dan menghambat. b) Terintegrasi, artinya literasi baca-tulis dikembangkan dan diimplementasikan dengan memadukan (mengintegrasikan) secara sistematis, menghubungkan dan merangkaikan secara harmonis, dan melekatkan literasi baca-tulis secara sinergis dengan yang lain, baik dalam hal kebijakan, program, kegiatan, maupun pelaksana dan berbagai pihak yang mendukung. Dalam belajar dan pembelajaran di sekolah, misalnya program dan kegiatan literasi baca-tulis perlu melekat secara sinergis dengan program dan kegiatan pembelajaran semua mata pelajaran. c) Sustainabilitas, atinya literasi baca-tulis dikembangkan dan diimplementasikan secara berkesinambungan, dinamis terus-menerus, dan berlanjut dari waktu ke waktu, tidak sekali jadi dan selesai dalam satuan waktu tertentu. d) Kontekstualitas, artinya kebijakan, strategi, program, dan kegiatan literasi baca-tulis dikembangkan dan diimplementasikan dengan mempertimbangkan konteks geografis, demografis, sosial, dan kultural yang ada di Indonesia. Oleh sebab itu, sekalipun terikat dengan kebijakan dan program pokok yang tercantum dalam Peta Jalan GLN, secara operasional pelaksanaan atau penerapan kebijakan, program, dan kegiatan literasi baca-tulis di Indonesia bisa beraneka ragam dan berbineka, tidak seragam dan sama. Misalnya, program, jenis, dan bahan kegiatan literasi baca-tulis di daerah urban, satelit, perdesaan, dan perbatasan dapat berbeda sesuai dengan karakteristik daerah masingmasing. e) Responsif Kearifan Lokal, artinya literasi baca-tulis tidak berada di ruang vakum sosial dan budaya serta tidak bisa dikembangkan dan diimplementasikan dengan mengabaikan, lebih-lebih menjadikan lokalitas sosial dan budaya. Agar gerakan literasi baca-tulis membumi dan berhasil tujuannya, pengembangan dan 
implementasi literasi baca-tulis perlu responsif dan adaptif terhadap kearifan lokal; kearifan lokal nusantara yang demikian kaya dan beragam perlu didayagunakan dan dimanfaatkan secara optimal dalam perencanaan dan pelaksanaan literasi baca-tulis di sekolah.

Menurut Saryono, dkk (2017: 10) indikator yang digunakan untuk mengukur kemampuan literasi baca-tulis di sekolah yaitu: a) Jumlah dan variasi bahan bacaan; b) Frekuensi peminjaman bahan bacaan di perpustakaan; c) Jumlah kegiatan sekolah yang berkaitan dengan literasi baca-tulis; d) Terdapat kebijakan sekolah mengenai literasi baca-tulis; e) Jumlah karya (tulisan) yang dihasilkan siswa dan guru; f) Terdapat komunitas baca-tulis di sekolah.

\section{Manfaat Pembacaan Cerita Pendek Terhadap Kemampuan Literasi Siswa}

Membaca merupakan kegiatan yang penting dalam kehidupan sehari-hari, karena membaca tidak hanya untuk memperoleh informasi, tetapi berfungsi sebagai alat untuk memperluas pengetahuan tentang banyak hal mengenai kehidupan. Rachmawati (2008: 4) menyebutkan manfaat membaca adalah sebagai berikut:a)Meningkatkan kadar intelektual; b) Memperoleh berbagai pengetahuan hidup; c) Memiliki cara pandang dan pola pikir yang luas; d) Memperkaya perbendaharaan kata; e) Mengetahui berbagai peristiwa yang terjadi di berbagai bahan dunia; f) Meningkatkan keimanan; g) Mendapatkan hiburan.

Menurut Somadya (2011: 11) membaca memiliki banyak manfaat diantaranya memperluas pengetahuan, bersenang-senang, menggali pesan-pesan tertulis dalam bahan bacaan, memperoleh banyak informasi, serta dapat mengikuti laju perkembangan zaman.

Rahim (2009: 1) menjelaskan manfaat yang diperoleh dari membaca yaitu memperoleh pengetahuan dan wawasan baru, termotivasi untuk belajar, meningkatkan kecerdasan, serta memperoleh banyak informasi yang dibutuhkan dalam kehidupan sehari-hari.

Berdasarkan beberapa pendapat di atas, dapat disimpulkan bahwa banyak manfaat yang diperoleh dari membaca, yaitu memperoleh banyak pengetahuan dan wawasan, memperoleh informasi, memperbanyak kosa kata, memperluas pengetahuan, serta menyiapkan diri untuk mengikuti perkembangan zaman.

Dengan menyadari betapa banyak manfaat membaca seperti yang telah dikemukakan di atas, guru dapat melatih kemampuan anak berliterasi mulai dari pembacaan teks cerita dimana dalam hal ini adalah cerita pendek karena sasaran fokus pada kajian ini adalah siswa SD terutama kelas rendah yang baru atau bahkan belum lancar membaca.

\section{KESIMPULAN}

Pembacaan cerita pendek merupakan kegiatan membaca suatu cerita fiktif naratif yang pendek sebagai langkah awal menanamkan budaya literasi anak.

Terdapat beberapa macam literasi, salah satunya literasi baca-tulis. Literasi baca-tulis merupakan sebuah pengetahuan dan kecakapan untuk membaca, menulis, mencari, menelusuri, mengolah dan memahami informasi untuk menganalisis, menanggapi, dan menggunakan teks tertulis untuk mencapai tujuan, mengembangkan pemahaman dan potensi, serta untuk berpartisipasi di lingkungan sosial. Literasi bacatulis merupakan literasi paling dasar yang diterapkan di sekolah dasar.

Salah satu upaya untuk meningkatkan literasi baca-tulis di sekolah dasar yaitu melalui pembacaan cerita pendek. Pembacaan cerita pendek mempunyai manfaat 
untuk memperolehbanyak pengetahuan dan wawasan, memperoleh informasi, memperbanyak kosa kata, meningkatkan ketrampilan menulis, memperluas pengetahuan, serta menyiapkan diri untuk mengikuti perkembangan zaman.

\section{DAFTAR PUSTAKA}

cnnindonesia. (2017). Mengapa Literasi di Indonesia Sangat Rendah.Diakses tanggal $2 \quad$ Oktober $\quad 2018 \quad$ pukul $16.00 \quad$ dari https://student.cnnindonesia.com/edukasi/20170910122629-445240706/mengapa-literasi-di-indonesia-sangat-terendah/

Ghazali, H.A.S. (2013). Pembelajaran Keterampilan Berbahasa dengan Pendekatan Komunikatif-Interaktif. Bandung: PT Refika Aditama

Haryadi. (2012). Retorika Membaca. Semarang: Rumah Indonesia Republika.com. (2018). Literasi Indonesia Sangat Rendah. Diakses tanggal 2 Oktober 2018 pukul 16.15 dari https://www.republika.co.id/amp_version/ngm3g840

Kompas.com. (2018). Per Hari, Rata-Rata Orang Indonesia Hanya Baca Buku Kurang dari Sejam. Diakses tanggal 11 Oktober 2018 pukul 22.12 dari https://nasional.kompas.com/read/2018/03/26/14432641/per-hari-rata-rata-orangindonesia-hanya-baca-buku-kurang-dari-sejam

Kurniawan, H. (2009). Sastra Anak. Yogyakarta: Graha IImu.

Rachmawati, F. (2008). Dunia di Balik Kata (Pintar Membaca). Yogyakarta: Gatra Aji Parama.

Rahim, F. (2009). Pengajaran Membaca di Sekolah Dasar. Jakarta: Bumi Aksara

Somadya, s. (2011). Strategi dan Teknik Pembelajaran Membaca. Yogyakarta: Graha IImu.

Saryono, dkk. (2017). Literasi baca Tulis. Jakarta: Kementerian Pendidikan dan Kebudayaan. 